\title{
The moral challenge of expatriate employment in developing countries
}

\author{
Uchenna Okeja
}

Department of Philosophy, Rhodes University and Stellenbosch Institute for Advanced Study, South Africa, u.okeja@ru.ac.za

DOI: http://dx.doi.org/10.5324/eip.v11i2.1985

(cc)BY This is an open access article distributed under the terms of the Creative Commons Attribution 4.0 International License, which permits unrestricted use, distribution, and reproduction in any medium, provided the original author and source are credited.

This paper contributes to the discourse on expatriate employment in developing countries. The aim is to determine whether or not the practice is morally objectionable and if so, to point out the most plausible way to account for the moral problem involved. In this regard, I examine four arguments, namely, that in developing countries, expatriate employment is morally wrong because it 1) entrenches the injustice of wage discrimination, 2) produces undesirable outcomes, 3) disregards contextual aspirations and historical memory and 4) is a tool of external domination and control. I analyse these arguments to show that they are insufficient accounts for the moral impropriety of expatriate employment in developing countries. To this end, I provide an outline of an argument I consider capable of accounting for the moral question in this context. This argument focuses on the notion that the moral problem of expatriate employment in developing countries is the unequal or arbitrary distribution of power among employees. The moral wrong in this, I argue, consists in the failure to respect the universal moral equality of people.

Keywords: expatriates, multi-national companies, developing countries, business ethics, compensation

\section{Introduction}

Given the enormous differences between the remuneration and general welfare packages of expatriates and the local staff of companies in developing countries, an important question that arises for business ethics in this context is the extent to which expatriate employment is a moral problem. The differences between the reliance on expatriate employment in profit-driven and non-profit organizations notwithstanding, remuneration for expatriates is mostly characterized by great disparities. I do not wish to provide an account of the differences between the practice of expatriation in for-profit and non-profit organizations. I will, however, draw on the perspectives put forward regarding expatriate employment in both contexts to determine whether or not the practice is morally objectionable and if so, the most plausible way to account for the moral objectionability. To contextualize my argument, I first discuss the prominent arguments decipherable from the literature regarding why expatriate employment is considered morally objectionable. Framing the positions taken into account as the arguments from 1) wage injustice, 
2) undesirability, 3) insensitivity to context and history and 4) domination, I argue that these perspectives are implausible ways of understanding the moral problem of expatriate employment in developing countries.

The wage injustice argument claims that expatriate employment in developing countries is morally wrong because it involves an unjust compensation practice. This argument attempts to derive the moral impropriety of expatriate employment in developing countries from the specific issue of wage disparity. The second argument, of undesirability, relates to the claim that expatriate employment in developing countries is wrong because of the undesirable outcomes associated with it. Undesirable outcomes, such as deflation of employee morale and the cost of expatriates' failure to achieve the goals their company sent them abroad, are generally considered to be grounds that demonstrate the moral shortcoming of this form of employment in developing countries. The third argument considers expatriate employment a morally indefensible practice because it is not sensitive to the push for indigenization. The claim is that expatriate employment obstructs the indigenous development of local capacities. Due to the colonial experience of developing countries, the point of the fourth argument is that expatriate employment is morally wrong because it perpetuates external domination and control.

As my analysis will reveal, these views are incapable of accounting for what exactly constitutes the moral impropriety of this form of human resource practice. This is the case because they do not suffice as plausible general frameworks to assess the moral rightness of this phenomenon in developing countries. Key to my thesis is the notion that expatriate employment in developing countries is morally wrong because it is inherently characterized by unequal or arbitrary distribution of power amongst employees. The moral wrong of this, I argue, is that the practice fails to respect the universal moral equality of human beings.

My argument in this paper departs from the convention of discussing expatriate employment in developing countries by merely assessing putative moral issues, such as wage discrimination and disparities in welfare packages. I aim instead to provide a general framework that accounts for the moral impropriety of the practice as a whole and not just some of its putative aspects. The claim I seek to defend should, however, not be interpreted to mean that I consider expatriate employees to be bad people or even that companies that engage in this kind of practice have negative attitudes towards the aspirations of developing countries. To be sure, expatriate employment could be a rational option for many profit and non-profit oriented organizations. However, in this paper I seek to propose a plausible ethical framework that is capable of telling us when expatriate employment in developing countries is morally indefensible. It is important to also point out that my effort in this paper does not extend to considering related but distinct questions. For one, since I only aim to provide a general framework that accounts for the moral impropriety of this practice, I do not try to determine whether expatriate employment is an economically advantageous practice for developing countries. Nor do I aim to establish the moral implications of the disparity between the compensation of expatriates and their home-country counterparts.

I begin the paper with a discussion of the expatriate phenomenon. In the second part of the paper, I consider the grounds for this practice from the perspective of company-initiated and self-initiated expatriation. Section three is devoted to articulating and analysing the arguments regarding the moral question of expatriate 
employment in developing countries. In section four, I provide the grounds for my thesis regarding expatriate employment in developing countries and defend my claim by invoking the concept of universal moral equality. This section concludes with a reflection on possible rebuttals to my thesis. In conclusion, I point out some implications of the views I have proposed for future research.

\section{The expatriate phenomenon}

When looked at from the dimension of etymology, this concept designates a very old practice. To be sure, ex patria designates the act of leaving (ex) one's country (patria). Seen in this light, expatriation could be taken to imply a range of movements to foreign countries, since what matters is the very act of leaving, rather than one's reason for leaving. So, men and women who travel to distant places to propagate their faith with missionary zeal are rightly regarded as expatriates. The list extends to professionals who are sent abroad by their company, foreign providers of expert knowledge or labour, different categories of immigrants, as well as representatives of governments, agencies and institutions on assignment in foreign countries.

The diversity of the themes studied by extant literature reveals the extent of the divergent meanings attributed to the concept. While some have attempted to make sense of the concept from the perspective of expatriate writers, like American expatriate writers in Paris in the 1920s (Cowley 1994; Papayanis 2005; Flanner 1988), others have studied it from the perspective of citizenship (Green \& Weil 2007) and pension and demography (Krieger 2005). Although etymology defines all these different categories of people studied in the literature as expatriates, contemporary business parlance does not subscribe to this definition. The reason for this is that a specific meaning of the concept has developed over the years in business literature.

A cursory look at the usage and understanding of the concept in business studies should suffice to buttress this point. In their classic study of expatriate employment, Edström \& Galbraith (1977: 249) proposed that the meaning of the concept is connected to the international movement of managers between central offices and subsidiaries. Although the researchers were concerned with this sort of human resource movement within European multinational organizations, their insights have had an enormous impact on the way business studies applies the concept. Subsequently, the concept has come to denote the practice of selecting and sending managers abroad for different purposes.

Recent studies identify two categories of expatriates, namely, self-initiated and company-initiated expatriates (Al Ariss \& Crowley-Henry 2013). The concept of self-initiated expatriate refers to professionals who voluntarily relocate abroad to take up a job, while the company-initiated form of expatriation refers to professionals sent on international assignment by their employers (Biemann \& Andresen 2010). Based on this distinction, a proper understanding of this concept includes in dividuals working abroad without institutional or organizational backing, as well as professionals who relocate abroad because they are sent by their companies. In this paper, I generally assume that expatriates are non-nationals who receive different reward or treatment at their workplace, mainly because of their place of origin. Expatriation in this sense may be self initiated or company initiated. However, in considering differences between the two categories, we find divergent 
motivating grounds for expatriation, despite the possibility of sharing some symmetries. Thus, it is important to review the motivating reasons for both types of expatriation.

\section{Motivations for expatriation}

Since engaging expatriates is obviously more expensive than hiring locally available human resources (Daniels \& Insch 2002), very compelling reasons are required to justify the practice. It is imperative to ask: why do global businesses hire expatriates? Although many reasons have been put forward to explain the cogency of international assignment, I will attempt to sort these explanations into two categories. The first category will enumerate the reasons behind company-initiated expatriation, while the second will focus on accounting for the grounds for selfinitiated expatriation.

Proposing that expatriation is a means of coordination and organizational control, Edström \& Galbraith note that its justification varies from company to company. They point out that one reason companies resort to expatriate employment is simply to "fill positions when qualified local individuals are not available or easily trained" (Edström \& Galbraith: 252). According to the researchers, this is usually the case when companies send expatriate personnel to developing countries. Edström \& Galbraith also suggest that companies engage expatriates in order to develop professionals for leadership positions, especially in organizations with a significant proportion of international activity. The point here is that even in a situation where highly qualified local professionals are available, companies will still resort to expatriation in order to give international experience to people in management positions with long term potential. Furthermore, companies sometimes send professionals on international assignment because of the opportunity such assignments create for the type of socialization that is crucial for organizational development (Edström \& Galbraith: 257).

Different metaphors have been used to explain the motivating grounds for selfinitiated expatriation (Richardson \& McKenna 2002, 2003; Selmer \& Lauring 2010; Doherty, Dickmann, and Mills 2011). The primary reasons for this type of expatriation are considered to be: 1) explorer instinct, 2) fleeing the familiar, 3) quest for better wages and 4) career development considerations. The first reason suggests that in dividuals decide to go abroad to work because they want to see more of the world and encounter new challenges and experiences. The second reason explains self-initiated expatriation as a quest to escape familiar practices at home that are either unfavourable or undesirable. The third reason that self-initiated expatriates choose to go abroad should be more or less self-evident, considering the enormous wage differences between different countries. That is, self-initiated expatriation occurs because an individual wishes to earn more money and increase savings for future considerations, such as family needs and children's education.

Furthering one's career prospects is also a motivation for self-initiated expatriation because international experience enhances one's competitive edge. Family considerations can be added to these reasons, especially where one relocates abroad to be with the people one loves and cherishes. Noting that the studies on expatriate employment focus excessively on the corporate executive sent on international assignment, Richardson \& McKenna suggest that "further research should be undertaken into self-selecting expatriates more generally and in order to 
build a more comprehensive picture of the 'motivation to go' and the experiences of expatriation" (Richardson \& McKenna 2002: 76).

\section{Articulating the moral challenge of expatriation}

Many moral concerns have been raised in the literature regarding expatriate employment, especially given the way the practice unfolds in developing countries. Four main arguments have been put forward to explain the moral problem of expatriate employment in developing countries, namely that the practice: 1) is premised on the injustice of wage discrimination (Toh \& DeNisi 2005; Chen, Kraemer, and Gathii 2011; Oltra, Bonache, and Brewster 2013; Bonache, Sanchez, and Zarraga-Oberty 2009), 2) produces undesirable outcomes (Carr, McLoughlin, Hodgson, and MacLachlan 1996), 3) disregards contextual aspirations and historical memory (Bhanugopan \& Fish 2007; Akinsanya 1980, 1994; Ogbuagu 1983; Rood 1976) and 4) perpetuates external domination and control (Smiley 2010; Manji \& O'Coill 2002).

The first argument stems from the enormous pay disparity between expatriates and local professionals. It has been noted that, although expatriates work shoulder to shoulder with similarly qualified local professionals (Welch 2003), expatriate salaries are usually considerably higher than those of local professionals. In some cases, this disparity could mean that expatriates earn as much as 20 to 50 times the salary of local professionals. In fact, in many cases, the housing allowance of an expatriate is higher than the salary of a local employee of similar rank (Chen, Choi, and Chi 2002: 808).

Viewed from the perspective of distributive justice, the moral problem here is very evident. Prima facie, it would strike one that this disparity is unfair because the two categories of employees make similar contributions to the company. The basic problem here is that local employees are treated like "second class citizens when working alongside expatriates in their own country" (Toh \& DeNisi 2005: 133). Given that "local-expatriate compensation disparity is not a regional issue unique to China or Asia, but one that exists in cross-national expatriation, especially between developed and developing countries" (Chen and others 2011: 3596), the argument made from this perspective is that expatriate employment in developing countries is morally indefensible, because it is a system premised on wage injustice and discrimination. The point here is that the phenomenon of compensation disparity between local employees and expatriates is not a regional issue restricted to the conventions of management practices in China or similar countries in Asia. In other words, enormous pay disparity is a feature of expatriate employment commonly experienced in most developing countries of the world.

Although different arguments have been put forward to explain the pay disparity between expatriates and local employees (Adams, 1963; Oltra and others 2013), the central problem is that these explanations do not sufficiently account for the entrenchment of this practice in companies and NGOs in developing countries. Thus, it would appear that a plausible construal of the moral problem of expatriate employment in developing countries is clearly the lack of fairness of compensation practices.

I do not dispute the importance of wage injustice in understanding the moral problem of expatriate employment in developing countries, but it does not seem to me that this is a reasonable way to construe the moral indefensibility of the practice. 
Other considerations are important in making sense of the moral issue here that are not related to compensation, such as power differences, fair distribution of work conditions and other non-material goods. The problem with the wage injustice approach is that it does not capture the entire scope of what is really at stake. To conclude that expatriate employment in developing countries is morally indefensible because of the lack of fairness in compensating expatriates and local employees is to commit a fallacy of faulty generalization. This approach simply takes the aspect of wage injustice as a defining feature that makes expatriate employment morally indefensible. So, while I think it is true that the compensation disparity between local employees and expatriates constitutes a form of injustice, I believe that a general framework for the construal of the moral problem must have a different starting point. Arguing from the perspective of wage injustice does not suffice to show what defines the moral impropriety of this form of employment in developing countries.

Another account of the moral indefensibility of expatriate employment in developing countries is embodied in studies seeking to demonstrate the adverse effects of expatriate employment. An example of this approach is a study of the impact of expatriate employment on the formal education sector in Malawi. In this study, it was noted that overall, the circumstances surrounding expatriate employment in this developing country led to the demotivation of both the local staff and expatriates (Carr, Chipande and MacLachlan 1998: 134 - 135) and consequently undermined the goal of the organization. Carr and MacLachlan (1996) have shown that in many cases pay differentials lead to double demotivation, that is, to the demotivation of expatriates as well as of local employees. Whereas this problem arises for the expatriate due to self-perception, the local employee is most often demotivated because of perceived unfairness. Thus, expatriate employment leads to negative outcomes that do not align with the goals of businesses or international charities. Self-perception is central to productivity in the workplace essentially "the mechanism by which those who are initially focused on the money may become demotivated" (Carr and others 1998: 134). Expatriates become demotivated because their judgement that they are "working just for the money" impacts their motivation and hence performance (Carr and others 1998: 134). This point largely explains the overall picture in the literature on NGOs that reliance on expatriate employment for the realization of organizational goals in developing countries leads to failure (Edwards 1996).

Based on these observations, expatriate employment in developing countries would be considered to be morally indefensible because it produces undesirable outcomes. This argument maintains that expatriate employment is a morally indefensible practice to adopt in developing countries, since it has been shown to lead to negative outcomes for expatriates, local employees and the organization or company. The reasoning for this claim is that it is irresponsible to adopt a practice (expatriation) that is known to lead to negative outcomes (demotivation), which undermine the realization of the interest of the company or organization.

The problem with this argument can be stated in the following way: if the moral indefensibility of expatriate employment is understood solely from the perspective of the negative outcomes it leads to, then this implies that no question of moral impropriety exists when the practice leads to positive outcomes. This perspective falls short, because what is at stake is not the outcome of the practice per se but the phenomenon itself. Specifically, the goal is to show what makes the basic nature of 
expatriate employment in developing countries morally indefensible. This is not a sufficient explanation of the moral problem because the argument deals solely with one putative moral aspect of the phenomenon and does not provide a general moral framework for the evaluation of this form of employment in developing countries.

The wave of indigenization in different sectors of the economies of many developing countries provides the grounds for the third argument regarding the moral problem of expatriate employment in developing countries (Ogbuagu 1983; Rood 1976; Akinsanya 1994). For many post-colonial states, the path to national development involved implementing policies that would enable the states to exercise significant control over the economic activities within their territories. Thus, the cogency of indigenization for these countries was premised on the negative implications of foreign control of their economies through expatriates. The following observation demonstrates this point:

In the pre-independence and early independence era, the Nigerian economy was dominated and controlled by foreign nationals.... The economic structure in this period can be likened to an hourglass: most foreign private investors and entrepreneurs (notably from Britain and other European industrialized countries) made up the highest echelon; other foreign nationals such as the Lebanese acted as middle-men, engaged primarily in distributive and export trade and other related services; and, at the base of the economic structure, were a few privileged Nigerian elites who performed very peripheral economic roles (Ogbuagu 1983: 242).

After independence, the leadership of the country attempted to bring the public and private sectors under the control of Nigerian nationals. This resulted in the Nigerian Enterprises Promotion Decree, which was enacted by the government in 1972 (Akinsanya 1994: 64). The aim of this decree was to ensure that expatriates were replaced by local professionals in order to fast track the realization of economic freedom in the newly independent country. To be sure, indigenization did not only occur in Nigeria. It also informed national business policies in the United Arab Emirates (Forstenlechner 2008; Al-Lamki 2005), Papua New Guinea (Bhanugopan \& Fish 2007) and many other developing countries.

Based on the concerns expressed in the debates about indigenization of the workforce in developing countries, expatriate employment in these countries is considered morally indefensible because it perpetuates a practice that is insensitive to the context and historical memory of these countries. Evidently, this argument owes its currency to the post-colonial nature of many of the developing countries striving to build modern economies. During the era of colonial economies in Africa and other parts of the world, the local staff constituted the lowest tier of the work force. Unlike expatriates, they held most of the menial jobs and had very few opportunities for career advancement. From this contextual space, the engagement of expatriates in both the public and private sectors of developing economies is argued to be morally indefensible because it entrenches a practice that obstructs the development of local capacities through the implementation of indigenization policies.

Apart from lacking proof of how exactly indigenization alone is capable of bringing about the desired results in the economy, this argument proceeds from the wrong end in making its case for the moral indefensibility of expatriate employment in developing countries. The argument adopts a third-person perspective, that of the context and historical memory of the local environment, 
instead of the responsibility-bearing agent - the company or organization engaging expatriates. Limiting what matters solely to the third-person perspective - the local context - renders the argument incapable of satisfactorily explaining the moral indefensibility of expatriate employment. To account for the moral impropriety of this form of employment, one needs to show a compelling reason why it is an objectively indefensible practice. Besides, since it is possible that a practice can undermine contextual aspirations without being morally indefensible, this argument fails to provide a plausible framework for understanding the moral problem of expatriate employment in developing countries.

A fourth argument holds the view that expatriate employment is a practice designed to perpetuate the external control and domination of people in developing countries. For instance, Sarah L. Smiley has argued in her analysis of the patterns of everyday life of expatriates in Dar es Salaam that "the perception of Dar es Salaam by expatriates, of its perceived safety and comfort, and the limited ways in which they use the city reinforces past patterns of segregation" (Sarah L. Smiley 2010: 339). If this observation is taken to mean that expatriate employment perpetuates patterns of domination reminiscent of the colonial era in developing countries, then one can argue on this basis that this form of employment is morally indefensible because it perpetuates domination.

Most of the literature critical of NGOs amplifies the claims of this argument. The main idea is that the role of NGOs "in 'development' represents a continuity of the work of their precursors, the missionaries and voluntary organizations that cooperated in Europe's colonization of and control of Africa. Today, their work contributes marginally to relief of poverty, but significantly to undermining the struggle of African people to emancipate themselves from economic, social and political oppression" (Manji \& O'Coill 2002: 568). Since NGO work in developing countries is almost synonymous with expatriates, this view reinforces the argument that expatriate employment in these countries is morally indefensible because it perpetuates domination.

Although I would concede that the relationship between expatriates and their host cities in developing countries is not always the best, I do not think it is plausible to argue solely on this ground that expatriate employment is a morally indefensible practice. As I see it, the only claim one can justify on this ground is that expatriate employment creates a moral problem in developing countries, specifically perpetuating the domination of the people in those countries. This being the case, the proper construal of the moral impropriety of expatriate employment in developing countries must be sought in another realm. I propose that a correct understanding of the moral problem of expatriate employment in developing countries is decipherable by directly investigating the nature of this form of employment rather than the analysis of its putative aspects.

\section{Making sense of the moral challenge of expatriation}

Since the arguments considered thus far are not viable ways of construing the moral problem of expatriate employment in developing countries, do we then declare the issue to be not just intractable but also beyond the scope of business ethics? It is hard to endorse this conclusion if we take seriously the calls for business ethics to be developed as an integral part of corporate culture in Africa (Rossouw 1994) and other developing regions of the world (Cheung, Tan, Ahn, and Zhang 2010). I think 
it is possible to articulate a plausible construal of the moral problem of expatriate employment in developing countries.

I suggest that power is central to the moral question of expatriate employment in developing countries. This form of employment is morally indefensible because it is inherently characterized by unequal or arbitrary distribution of power amongst employees. Unequal distribution of power occurs when the distribution process allows for a deficit which is to the advantage of expatriates over similarly qualified local staff, or vice versa. On the other hand, arbitrary distribution of power occurs when the distribution process allows for the privileging of less qualified expatriates over all local staff or less qualified local staff over all expatriates. So, when power is arbitrarily distributed, for instance, expatriates who are less qualified, less experienced or perform lower level tasks, are privileged over local staff who are better qualified, more experienced and assigned higher level tasks.

Thus, the moral problem of expatriate employment in developing countries stems from the unequal or arbitrary distribution of power among employees. The issue here is that this form of employment always implies that some employees are granted more power than their counterparts. This can manifest itself in some cases as un equal distribution of power and in other cases as arbitrary distribution of power in the sense described above. To be sure, the problem could also manifest itself as a combination of both forms of distribution of power. However, the mere fact that expatriate employment in developing countries is inherently characterized by arbitrary or unequal distribution of power does not demonstrate why this is morally wrong. Why, in other words, is this arbitrary or unequal distribution of power morally wrong? In what does this moral wrong consist?

To my mind, the moral wrong here consists in the disregard of this type of situation for the universal moral equality of human beings. Basically, universal moral equality is the view that every human being matters morally in the same way and thus should be treated with equal respect and concern. As Joel Feinberg has argued, "the real point of the maxim that all men are equal may be simply that all men equally have a point of view of their own, a unique angle from which they view the world. They are all equally centres of experience, foci of subjectivity. This implies that they are all capable of being viewed by others imaginatively from their own point of view. They 'have shoes' into which we can always try to put ourselves" (Feinberg 1973: 93). The moral equality of persons demands that we develop an attitude of respect towards the humanity of each person. If one accepts that the universal moral equality of human beings implies treating everyone with equal respect and concern, then it will become obvious why expatriate employment in developing countries, which is inherently characterized by unequal or arbitrary distribution of power, is wrong. In its current manifestation, expatriate employment in developing countries is morally indefensible because it does not reflect an attitude of respect of the moral equality of all employees.

One can of course argue that this proposition regarding the nature of the moral impropriety of expatriate employment in developing countries does not adequately note the importance of incentives. This claim would suggest that companies must offer incentives to expatriates to get them to move abroad. So, expatriate employment cannot but be essentially characterized by unequal or arbitrary distribution of power. The implication of this argument is that expatriates in developing countries come from a better state of affairs to one that is less desirable. Indeed, it has been argued that the current status quo regarding expatriate 
employment subsists because it is supposed to encourage people to go and work in places where the living standards are significantly lower (Reynolds 1997).

This argument does not adequately justify the current nature of expatriate employment in developing countries, because it misunderstands the problem of unequal or arbitrary distribution of power as something that always favours expatriates. My proposition does not limit the context of this unequal or arbitrary distribution of power to the sort of relation implied by the argument from incentives. It is perfectly in line with my proposal to conceive of the unequal or arbitrary distribution of power manifesting in such a way that the inequality or arbitrariness favours the local staff, as for instance in the case of expatriate employment in the oil-producing Arab States of the Persian Gulf. My proposal captures the nature of the moral problem here, namely that expatriate employment in developing countries is morally indefensible because it distributes power unequally or arbitrarily amongst employees.

Another rebuttal that could be articulated to dispute the validity of the proposal I have outlined is that my argument misunderstands the nature of corporate human resource practices in global businesses. This rebuttal would propose that it is not plausible to construe the moral problem of expatriate employment in developing countries from the perspective of un equal or arbitrary distribution of power, because expatriates have different skills that distinguish them from local staff. On this basis, this counterargument would propose that the differential treatment of different categories of employees does not mean that a scheme of unequal or arbitrary distribution of power is endorsed.

The problem with this rebuttal is its propensity to lead to absurd conclusions. As a normative viewpoint, the argument could be deployed to justify various forms of oppression or discrimination in business interaction. So, from this viewpoint, one could claim that rewarding different genders differently is not morally problematic because it is just a situation where different people are valued differently. Secondly, this counterargument misconstrues the nature of the moral problem of expatriate employment in developing countries, because it does not recognize that the moral problem here arises due to either unequal or arbitrary distribution of power. In the case of unequal distribution of power, the issue pertains to employees who have equal qualifications, experience or are charged with the performance of similar tasks. My proposal does not imply that there can be no differences in pay for various categories of employees. Rather, I suggest that expatriate employment in developing countries inherently admits inequality of power for the same category of employees.

\section{Conclusion}

Gideon Rossouw (1994: 43) made a very plausible claim when he argued that business ethics should be seen as a concern in developing countries, just like one finds in developed countries. Today, this notion has become even more urgent because of problems related to fair trade, sustainable and responsible supply chains, insider trading in non-ideal situations, bribery and corruption, cross cultural factors in negotiation and child labour. In this paper, my concern has been to provide a general framework for understanding the business ethics problem of expatriate employment in developing countries.

I have argued that the moral problem of expatriate employment in this context relates to the issue of power, specifically the unequal or arbitrary distribution of 
power amongst employees. In this light, expatriate employment in developing countries is morally indefensible because it is inherently characterized by unequal or arbitrary distribution of power. The reason for this, I have argued, is the implicit disrespect of the universal moral equality of people. My proposal implies that research on business ethics needs to do more than evaluate the moral implications of putative aspects of business practices. It is imperative to attempt to provide general frameworks for the understanding of business ethics problems.

I have not argued, however, that expatriates are bad people. In addition, I have also not attempted to demonstrate on empirical grounds that this form of employment is economically advantageous or vice versa for developing countries. To be sure, good pragmatic reasons support many companies resorting to expatriation. The main issue, however, is that the consideration of the morality of this practice in developing countries requires us to evaluate the manifestation of the phenomenon in this context in addition to the pragmatic reasons that account for companies' reliance on the practice. This explains why the argument I have provided in this paper would imply that expatriate employment in developing countries will become a morally unproblematic phenomenon only when it is no longer inherently characterized by unequal or arbitrary distribution of power. Good pragmatic reasons, such as we find in the argument put forward by Edström \& Galbraith (Edström \& Galbraith: 257) - that expatriation is a way of distributing opportunities for career development among employees - need to recognize further moral imperatives in order for the practice to be morally acceptable. Questions regarding the empirical grounds for expatriation will require a different kind of study, which I am not able to provide in the present paper. However, even if expatriate employment were empirically shown to be economically advantageous in developing countries, the question regarding its moral propriety, which I have addressed in this paper, would still need to be asked.

\section{References}

Adams, J. S. (1963). Wage Inequities, Productivity and Work Quality. Industrial Relations, 3(1), 9-16. https://doi.org/10.1111/j.1468-232X.1963.tb00805.x

Akinsanya, A. (1994). The Power Structure in Nigeria and the Indigenization of the Economy. Pakistan Horizon, 47(2), 63-79.

Akinsanya, A. (1980). The Expropriation of Multinational Property in the Third World. New York: Praeger.

Al Ariss, A. and Crowley-Henry, M. (2013). Self-initiated Expatriation and Migration in the Management Literature: Present Theorizations and Future Research Directions. Career Development International, 18(1), 78-96. https://doi.org/10.1108/13620431311305962

Al-Lamki, S. M. (2005). The Role of the Private Sector in Omanization: The Case of the Banking Industry in the Sultanate of Oman. International Journal of Management, 22(2), 176-188.

Bhanugopan, R. and Fish, A. (2007). Replacing Expatriates with Local Managers: An Exploratory Investigation into Obstacles to Localization in a Developing Country. Human Resource Development International, 10(4), 365-381. https://doi.org/10.1080/13678860701718695

Biemann, T. and Andresen, M. (2010). Self-initiated Foreign Expatriates versus Assigned Expatriates: Two Distinct Types of International Careers? Journal of 
Managerial Psychology, 25(4), 430-448. https://doi.org/10.1108/0268394101 1035313

Bonache, J., Sanchez, J. I. and Zarraga-Oberty, C. (2009). The Interaction of Expatriate Pay Differential and Expatriate Inputs on Host Country Nationals' Pay Unfairness. The International Journal of Human Resource Management, 20(10), 2135-2149. https://doi.org/10.1080/09585190903178062

Carr, S. C., Chipande, R. and MacLachlan, M. (1998). Expatriate Aid Salaries in Malawi: A Doubly Demotivating Influence? International Journal of Educational Development, 18(2), 133-143. https://doi.org/10.1016/S07380593(97)00040-0

Carr, S. C., McLoughlin, D., Hodgson, M. and MacLachlan, M. (1996). Equity Sensitivity and Double Demotivation. Genetic, Social and GeneraI Psychology Monographs, 122(4), 475-494.

Chen, C. C., Choi, J. and Chi, S-C. (2002). Making Justice Sense of Local-expatriate Compensation Disparity: Mitigation by Local Referents, Ideological Explanations, and Interpersonal Sensitivity in China-foreign Joint Ventures. Academy of Management Journal, 45(4), 807-817. https://doi.org/10.2307/ 3069313

Chen, C. C., Kraemer, J. and Gathii, J. (2011). Understanding Locals' Compensation Fairness vis-à-vis Foreign Expatriates: The Role of Perceived Equity. The International Journal of Human Resource Management, 22(17), 3582-3600. https://doi.org/10.1080/09585192.2011.560873

Cheung, Y. L., Tan, W., Ahn, H-J. and Zhang, Z. (2010). Does Corporate Social Responsibility Matter in Asian Emerging Markets? Journal of Business Ethics, 92(3), 401-413. https://doi.org/10.1007/s10551-009-0164-3

Cowley, M. (1994). Exile's Return: A Literary Odyssey of the 1920s. New York: Penguin Books.

DeLisle, P. and Chin, S. (1994). Remunerating Employees in China - The Complicated Task Faced by Foreign Firms. Benefits and Compensation International, 24(2), 16-22.

Doherty, N., Dickmann, M. and Mills, T. (2011). Exploring the Motives of Company-backed and Self-initiated Expatriates. The International Journal of Human Resource Management, 22(3), 595-611. https://doi.org/10.1080/ 09585192.2011 .543637

Edström, A. and Galbraith J. R. (1977). Transfer of Managers as a Coordination and Control Strategy in Multinational Organizations. Administrative Science Quarterly, 22(2), 248-263. https://doi.org/10.2307/2391959

Edwards, M. (1996). NGO Performance - What Breeds Success? A Study of Approaches to Work in South Asia. Save The Children Fund Working Paper, 14.

Feinberg, J. (1973). Social Philosophy. Englewood Cliff: Prentice Hall.

Flanner, J. (1988). Paris Was Yesterday: 1925-1939. San Diego: Harcourt Brace Jovanovich.

Forstenlecher, I. (2008). Workforce Nationalization in the UAE: Image versus Integration. Education, Business and Society: Contemporary Middle Eastern Issues, 1(2), 82-91. https://doi.org/10.1108/17537980810890275

Green, N. L. \& Weil, F. (2007). Citizenship and those who leave: The Politics of Emigration and Expatriation. Urbana-Champaign: University of Illinois Press. 
Insch, G.S. and Daniels, J.O. (2002). Causes and Consequences of Declining Early Departures from Foreign Assignments. Business Horizons, 45(6), 39-48. https://doi.org/10.1016/S0007-6813(02)00259-8

Krieger, T. (2005). Public Pensions and Immigration: A Public Choice Approach. Cheltenham: Edward Elgar Publishing.

Manji, F. and O'Coill, C. (2002). The Missionary Position: NGO and Development in Africa. International Affairs, 78(3), 567-583. https://doi.org/10.1111/14682346.00267

Ogbuagu, C. S. A. (1983). The Nigerian Indigenization Policy: Nationalism or Pragmatism? African Affairs, 82(327), 241-266. https://doi.org/10.1093/ oxfordjournals.afraf.a097509

Oltra, V., Bonache, J. and Brewster, C. (2013). A New Framework for Understanding Inequalities between Expatriates and Host Country Nationals. Journal of Business Ethics, 115(2), 291-310. https://doi.org/10.1007/s10551012-1397-0

Papayanis, M. A. (2005). Writing in the Margins: The Ethics of Expatriation from Lawrence to Ondaatje. Nashville: Vanderbilt University Press.

Reynolds, C. (1997). Expatriate Compensation in Historical Perspective. Journal of World Business, 32(2), 118-132. https://doi.org/10.1016/S1090-9516(97) 90003-1

Richardson, J. and McKenna, S. (2002). Leaving and Experiencing: Why Academics expatriate and How they Experience Expatriation. Career Development International, 7(2), 67-78. https://doi.org/10.1108/13620430210421614

Richardson, J. and McKenna S. (2003). International Experience and Academic Careers: What do Academics Have to Say? Personal Review, 32(6), 774-795. https://doi.org/10.1108/00483480310498710

Rood, L. L. (1976). Nationalisation and Indigenisation in Africa. The Journal of Modern African Studies, 14(3), 427-447. https://doi.org/10.1017/S0022278X 00053507

Rossouw, G. I. (1994). Business Ethics in Developing Countries. Business Ethics Quarterly, 4(1), 43-51. https://doi.org/10.2307/3857558

Selmer, J. and Lauring J. (2010). Self-Initiated Academic Expatriates: Inherent Demographics and Reasons to Expatriate. European Management Review, 7(3), 169-179. https://doi.org/10.1057/emr.2010.15

Smiley, S. L. (2010). Expatriate Everyday Life in Dar es Salaam, Tanzania: Colonial Origins and Contemporary Legacies. Social and Cultural Geography, 11(4), 327-342. https://doi.org/10.1080/14649361003774555

Toh, S. M. and DeNisi, A. S. (2005). A Local Perspective to Expatriate Success. Academy of Management Executive, 19(1), 132-146.

Welch D. E. (2003). Globalization and Staff Movements: Beyond Cultural Adjustment. Management International Review, 43(2), 149-169. 